\title{
A Study on the Career Development Patterns of Special Education Needs Students in the High School Stage
}

\author{
Chau Hsiao Lan
}

\begin{abstract}
This study used the "Career Development Patterns Scale" to investigate and analyze the career development patterns of 325 sophomores with special education needs in general high schools in Taiwan. For the data of the scale, this study used the SPSS18.0 version to perform descriptive statistics, one-way ANOVA, percentage compliance and single sample t-test. The main findings are as follows: 1) the score of male students in realistic pattern and investigative pattern is higher than that of female students; the score of female students in artistic pattern and social pattern is higher than that of male students; most of the female students are in humanity pattern, and most of the male students are in the mathematics and physics pattern; 2) the score of students with severe/extremely severe disability in conventional pattern is higher than that of students with other levels of disability; 3 ) the choice of academic groups affects career development pattern; the score of students choosing the second group in investigative pattern is higher than that of those choosing the first group; the score of students choosing the second and third groups in mathematics and physics pattern is higher than that of those choosing the first group; 4) the percentage compliance between students choosing different groups and advantaged career development patterns is $65.24 \%$, suggesting that approximately $35 \%$ of the students fail to choose adequate groups; the compliance rate of female students is higher than that of male students; the compliance rate of students with mild and medium disability is also higher; 5) there is a significant difference in five career development patterns between general students and those with physical and psychological disability; the score of female students with special education needs in social pattern and humanity pattern is higher than that of general students.
\end{abstract}

In addition to proposing future research directions, this study also suggested high schools should provide career development strategies different from those from general high school student to special education needs students (SEN students), take into account the gender of level of disability and incorporate advanced career development patterns to assist SEN students to acquire more adequate career development.

Index Terms-Career development pattern, general high school, special education needs students.

\section{INTRODUCTION}

American School Counselor Association (ASCA) indicated that school guidance counseling should help improve students' development of 3 major fields: academic, career and individual/social development [1]. The criteria for counseling on career develop include: 1) students should acquire the skills for exploring the world of work that is associated with their self-knowledge to make wise career decision; 2) students should be able to use strategies to

Manuscript received November 1, 2013; revised January 15, 2014.

Chau Hsiao Lan is with National Taipei University of Education, Taiwan, ROC (e-mail: tsousl@gmail.com). successfully achieve their future career goals of self-satisfaction; 3 ) students should be able to understand the relationship among personal traits, education and training [2]. One of the educational objectives of general high schools is to enhance students' self-understanding and career development ability. In 2006, Ministry of Education implemented High School Physics Temporary Curriculum Guidelines to include career planning as a course, and developed Career Planning Course Guidelines in 2008 [3] to enable students to understand the relationship between personal development and career planning and use career planning-related resources to improve basic skills to career planning, further make career choice and develop forward-looking attitude and faith. The focus of career development is not on the planning of admission system, but on whether the post-admission counseling provided can improve students' self-understanding and trigger their advantaged career development. According to the data of 2012 Annual Statistical Report on Special Education of Ministry of Education [4], there were as many as 11,521 college students studying in colleges. Compared to 7,882 in 2006 academic year [5], the number rapidly increased by 3,639 within 5 years. At present, the college admission rate in Taiwan reaches $95 \%$ and above. Studying in college has become the main career choice of high school graduates.

SEN students tend to be affected by the factors that are unfavorable to their career development, such as early education failing to meet their needs, lack of life experiences and role learning opportunity, lack of career awareness and exploration, etc. A student with congenital cardiac disease, Kao, who was admitted to a famous senior high school, said, "My dream is to become a baker and open my own small bakery. However, my junior high school teachers all encouraged me to study here. My school principal even had a meeting with me to request me not to give up this chance." Some SEN students had never thought about these questions: "I study here because this is the school that every student intends to study." "I was accidentally admitted to this school because my scores were high enough." Career development is a dynamic process. The career development of SEN students is even more complicated. Such development is not a linear development, and there is no common law. Career decision-making is affected by multiple factors with the change of time, including individual, family, school and community. Individual factors, such as self-esteem, self-efficacy, career expectation and life satisfaction, all will affect career development [6]. Many studies pointed out that the factors affecting the career development of SEN students at the stage of high school include family environment, school environment and individual factors, such as personal traits, interest, ability, etc. [7]-[9]. [10] conducted a 
questionnaire survey on 1,240 SEN students in normal class of high schools, and found that the adaptation of students with learning disability, severe emotional disorder, autism and mental retardation is poorer. In general, the life adaptation of female students is better than that of male ones. The environmental adaptation of juniors was better than that of freshmen and sophomores. [11] Selected 151 SEN students and 156 general students (307 students totally) in high schools as the subjects, and found that the career skills and self-concept of SEN students in normal class are significantly lower than those of general students. [12] Conducted a comparative study on the career maturity and behavioral functions of 120 students with learning disability, students with emotional disability and general students, and also found that the career maturity of students with learning disability and emotional disability is significantly lower than that of general students. According to the studies mentioned above, the predicament of career development faced by SEN students is relatively high. Some of the SEN students did not plan for their future, and suggested that their major does not comply with their future development. They also seldom participated in employment activities. They were not ready for their future career preparation, and extremely needed assistance.

Based on the above, apparently, post-admission adaptation is the beginning of career development issues. To prevent high school graduates from choosing wrong major in college, it is important to provide career development counseling at the stage of senior high school. Super indicated that, individual life is affected by individual role and style at different stages of life. In addition, individual life is a continuous cycling process [13]. In other words, specific career and occupations are suitable for individuals with specific ability, interest and traits. Ability, interest and traits are further developed through various stages of growth and exploration, and they may experience the processes of maintenance, decline and transformation to gradually form various unique "career patterns." Therefore, the factors affecting career development is never in a single dimension. The stage of adolescence is a critical stage of career development where students experience the challenges and tests in senior high school. The primary objective of this study is to understand how to help SEN students face career change again and make the right choice over career development direction during the pre-college admission transition period based on the analysis of career development patterns. [14] Developed the career development patterns scale (CDPS) based on the concept of patterns, including realistic pattern, investigative pattern, artistic pattern, social pattern, enterprise pattern, conventional pattern, humanity pattern and mathematics and physics pattern. These 8 patterns can be divided into two major patterns, occupational career pattern <former six > and academic career pattern $<$ latter 2> according to the concept of career. The research results showed that, the score of male students in realistic pattern and investigative pattern is significantly higher than that of female ones. The score of female students in artistic pattern and social pattern is significantly higher than that of male ones. There is no significant gender difference in enterprise pattern and conventional pattern. This study intends to investigate whether SEN students are also affected by gender and similar distribution is found them based on the aforementioned results. Moreover, this study also intends to understand whether types and levels of disabilities affect the career development patterns of SEN students. This study compared the difference in career development patterns between SEN students and general students. More importantly, this study investigated by the compliance between choice of mathematics and physics pattern and their career development patterns from the perspective of advantaged career development to assist SEN students in properly making career choice. Based on the above, there are two objectives in this study: (1) to investigate the general status of career development patterns of SEN students at the stage of high school and the compliance of academic group; (2) to analyze and compare the difference in career development patterns between general students and SEN students at the stage of high school.

\section{METHOD}

This study conducted a questionnaire survey, and mainly selected the sophomores in normal class of public and private high schools in Taiwan who received the services of resource classroom during the period of this study as the subjects. This study used purposive sampling to select 72 schools according to the proportion of resource classroom established in general high schools in Taiwan. 360 questionnaires were distributed, and 346 questionnaires were returned from 67 schools. After the invalid questionnaires were excluded, there were 325 valid questionnaires, with a valid return rate of $90.3 \%$. Due to the uniqueness of the subjects, this study provided 4 types of completing methods. 314 subjects $(96.3 \%)$ read and completed the questionnaires on their own. Only 2 subjects $(0.6 \%)$ read the questionnaires on their own, and had other people complete the questionnaires in lieu of them. Three subjects $(0.9 \%)$ understood the questionnaires via audio description, and completed the questionnaires on their own. 7 subjects $(2.1 \%)$ understood the questionnaires via audio description and had other people complete the questionnaires in lieu of them.

This study used the CDPS developed by [14] to investigate and analyze the career development patterns of SEN students. The scale includes four parts, including "work value," "occupational interest," "multiple intelligences" and "academic performance," with 139 items totally. A 5-point scale was applied to this scale for selection of answers. The test-retest reliabilities of the subscales ranged from .90 to .98 , while their Cronbach's $\alpha$ coefficients ranged from .87 to .95 , criterion-related validities were between .30 and .73 .

After the questionnaires were returned, this study used SPSS18.0 version to perform descriptive statistical analysis, and used one-way ANOVA to test how the difference in variables, such as gender, types and levels of disabilities, and choice of academic group, affects their career development patterns. This study then used percentage compliance to analyze the compliance between the choice of academic group of SEN students and their advantaged career development patterns. In the end, this study used single-sample t-test to analyze the difference and similarly in career development patterns between general students and SEN students. 


\section{RESUltS AND DisCUSSION}

A total of 194 male students $(59.7 \%)$ and 131 female students $(40.3 \%)$ completed the CDPS. The male to female ratio of the subjects was 1.5:1. In terms of types of disabilities, most of the subjects were suffered from learning disability (16.3\%), followed by physical disability and autism (49 subjects; $15.0 \%$, respectively), hearing and speech disability (40 subjects and 30 subjects; $12.3 \%$ and $9.2 \%$, respectively), emotional and behavioral disability (24 subjects; $7.4 \%$ ), physical illness (21 subjects; 6.4\%), multiple disabilities (12 subjects), intellectual disability (11 subjects) and language disability (3 subjects; 0.9\%). According to the Disability Card, other types of disabilities also include cerebellar atrophy, mitochondrial disease and neurofibromatosis, facial trauma and epilepsy (18 subjects). In addition, 6 subjects did not tick the box of types of disabilities. In Taiwan, students in high schools are categorized into three different academic groups. In terms of choice of academic group, there were 215 subjects in the first group (male: 120; female: 95) $(67.2 \%)$. There were 62 subjects in the second group (male: 45; female: 17) $(19.4 \%)$. There were 43 subjects (male: 25 ; female: 18$)$ in the third group (13.4\%). In terms of levels of disabilities, most of the subjects suffered from mild disability (151; $47.2 \%$ ), followed by severe/extremely severe disability (49; $15.3 \%)$ and moderate and moderate to severe disability (42;
$13.1 \%)$. A higher proportion of subjects ticked the box of other levels (78 subjects; $24.4 \%$ ). Moreover, there were a total of 18 twice exceptional students $(5.5 \%)$, including 1 gifted music student with emotional and behavioral disability, 3 gifted language students, 2 gifted mathematics and physics students, 1 specially gifted student and 11 gifted art students. This small proportion of subjects are worthy of further follow-up and counseling.

\section{A. General Status of Career Development Patterns of SEN Students and Compliance of Academic Group}

Table $\mathrm{I}$ is the analysis on the variation of 8 career development patterns of male and female students. The result showed that there was a significant difference (Wilks' Lambda value .823, $p=.000$ ). According to the comparison, the score of male subjects in realistic pattern and investigative pattern was higher than that of female ones. The score of female subjects in artistic pattern and social pattern was higher than that of male ones. In terms of academic career pattern, female subjects preferred humanity pattern, while male subjects preferred mathematics and physics pattern. Such career development patterns is consistent with those observed in the comparative study on career development patterns of male and female students in general high schools by [14].

TABLE I: SUMMARY OF ONE-WAY ANOVA ON THE CDPS OF SEN STUDENTS WITH DIFFERENT GENDER $(N=325)$

\begin{tabular}{|c|c|c|c|c|c|c|c|c|}
\hline \multirow{2}{*}{$\begin{array}{l}\text { Career } \\
\text { Development } \\
\text { Patterns }\end{array}$} & \multicolumn{2}{|c|}{ Male $(n=194)$} & \multicolumn{2}{|c|}{ Female $(n=131)$} & \multirow[t]{2}{*}{ Wilks' $\Lambda$} & \multirow[t]{2}{*}{$p$} & \multirow[t]{2}{*}{$\eta^{2}$} & \multirow[t]{2}{*}{ Comparison } \\
\hline & $M$ & $S D$ & $M$ & $S D$ & & & & \\
\hline Realistic & 39.56 & 19.42 & 29.43 & 17.99 & & & & male>female \\
\hline Investigative & 38.13 & 19.61 & 31.08 & 17.72 & & & & male>female \\
\hline Artistic & 40.05 & 19.34 & 45.60 & 18.38 & & & & female $>$ male \\
\hline Social & 46.26 & 17.37 & 53.64 & 16.48 & & & & female $>$ male \\
\hline Enterprise & 50.47 & 12.57 & 50.55 & 12.41 & .823 & .000 & .177 & \\
\hline Conventional & 35.41 & 22.49 & 35.21 & 23.52 & & & & \\
\hline Humanity & 48.04 & 13.86 & 52.75 & 14.42 & & & & female $>$ male \\
\hline $\begin{array}{l}\text { Mathematics and } \\
\text { physics }\end{array}$ & 43.82 & 15.23 & 37.19 & 14.07 & & & & male>female \\
\hline
\end{tabular}

Table II is the analysis on the variation of 8 career development patterns of students with mild, moderate to severe, severe/extremely severe and other physical and psychological disabilities. The result showed that there was also a significant difference (Wilks' Lambda value .864, $p=.046<.05$ ). The score of students with severe/extremely severe disability in conventional pattern is higher than that of those with other unspecified levels of disabilities.

Furthermore, the result of the analysis on the variation of students studying in the first group, second group and third group and 8 career development patterns showed that Wilks'
Lambda value .909, $p=.019<.05$. According to the result of further comparison in Table III, the score of the second group students in the investigative pattern was higher than that of the first group ones. The second and the third group students in mathematics and physics pattern were higher than that of the first group ones. Because investigative pattern and mathematics and physics pattern are less suitable for the students in the first group, the result showed that the choice of academic group quite fits career development patterns.

TABLE II: ONE-WAY ANOVA ON THE CDPS OF SEN STUDENTS WITH DIFFERENT LEVELS $(N=320)$

\begin{tabular}{|c|c|c|c|c|c|c|c|c|c|c|c|c|}
\hline \multirow{2}{*}{$\begin{array}{c}\text { Career } \\
\text { Development } \\
\text { Patterns }\end{array}$} & \multicolumn{2}{|c|}{$\begin{array}{c}\text { Mild } \\
(n=151)\end{array}$} & \multicolumn{2}{|c|}{$\begin{array}{l}\text { Moderate to Severe } \\
\qquad(n=42)\end{array}$} & \multicolumn{2}{|c|}{$\begin{array}{r}\text { Severe/Extremely } \\
\text { Severe }(n=49)\end{array}$} & \multicolumn{2}{|r|}{$\begin{array}{c}\text { Others } \\
(n= \\
78) \\
\end{array}$} & \multirow[t]{2}{*}{$\begin{array}{c}\text { Wilks' } \\
\Lambda\end{array}$} & \multirow[t]{2}{*}{$p$} & \multirow[t]{2}{*}{$\eta^{2}$} & \multirow[t]{2}{*}{ Comparison } \\
\hline & $M$ & $S D$ & $M$ & $S D$ & $M$ & $S D$ & $M$ & $S D$ & & & & \\
\hline Realistic & 35.66 & 20.40 & 34.78 & 17.78 & 33.93 & 20.66 & 36.30 & 18.34 & \multirow{8}{*}{.864} & \multirow{8}{*}{.046} & \multirow{8}{*}{.036} & \\
\hline Investigative & 36.69 & 19.71 & 33.95 & 19.05 & 33.09 & 20.16 & 32.53 & 17.98 & & & & \\
\hline Artistic & 41.94 & 19.93 & 41.84 & 17.70 & 43.03 & 19.44 & 42.64 & 18.42 & & & & \\
\hline Social & 41.46 & 12.77 & 49.30 & 16.94 & 51.59 & 18.24 & 48.14 & 18.60 & & & & \\
\hline Enterprise & 51.66 & 12.81 & 52.05 & 12.16 & 50.03 & 13.18 & 47.85 & 11.50 & & & & \\
\hline Conventional & 35.99 & 22.73 & 41.15 & 23.21 & 41.01 & 23.10 & 28.12 & 21.62 & & & & severe>others \\
\hline Humanity & 50.36 & 14.19 & 49.76 & 12.74 & 51.93 & 15.53 & 47.97 & 14.22 & & & & \\
\hline Math \& physics & 42.18 & 16.10 & 39.92 & 14.75 & 41.26 & 15.75 & 39.53 & 15.11 & & & & \\
\hline
\end{tabular}


TABLE III: ANALYSIS ON THE VARIATION OF CDPS OF SEN STUDENTS IN DIFFERENT ACADEMIC GROUPS $(N=320)$

\begin{tabular}{|c|c|c|c|c|}
\hline Career Development Pattern & $F$ & $p$ & Post-hoc comparison & $\eta^{2}$ \\
\hline Realistic & 4.166 & .601 & & .026 \\
\hline Investigative & 5.496 & .005 & $2>1$ & .034 \\
\hline Artistic & .208 & .812 & & .001 \\
\hline Social & .604 & .547 & & .004 \\
\hline Enterprise & .866 & .422 & & .005 \\
\hline Conventional & 1.513 & .222 & & .009 \\
\hline Humanity & .127 & .881 & & .001 \\
\hline Mathematics and physics & 6.614 & .002 & $2>1,3>1$ & .040 \\
\hline
\end{tabular}

To understand the compliance between advantaged career development patterns of SEN students and their choice of academic group in senior high school, as well as the compliance between students with advantaged career development patterns of different gender and levels of disabilities and their choice of academic group, this study divided the investigative pattern and realistic pattern as the second and third groups, and divided artistic pattern, social pattern, enterprise pattern and conventional pattern as the first group. In addition, the subjects whose $\mathrm{T}$ score of career development pattern $\geqq 60$ were regarded as those of advantaged career development patterns. The analysis results are summarized in Table IV. The percentage compliance between advantaged career development patterns of the subjects and their choice of group of study was $65.24 \%$, suggesting that $65 \%$ of the students could chose the academic group suitable for them according to their interest, ability and advantage. The percentage compliance of students in the first group was particularly as high as $73.6 \%$. However, $35 \%$ of the SEN students failed to choose the academic group suitable for them. The result of the Chi-square test was 0.5 , reaching the significance, suggesting that there was a difference between choice of academic group and advantaged career development patterns. The analysis on male and female students showed that the compliance of male students was $63.2 \%$, and that of female ones was $68.1 \%$. The compliance between female students' choice of academic group and their advantaged career development patterns was higher. In addition, there was no difference between students in different academic groups. The result is inconsistent with that of the study by [14], which pointed that $20 \%$ of the general high school students may choose the wrong academic groups, and the wrong choice rate of female students is slightly higher than that of male ones. The comparison on students of different levels of disabilities found that the compliance between the choice of academic group of students with mild disability and their advantaged career development patterns increased to $70.4 \%$ and that of students with moderate to severe disability increased to $72.7 \%$. It may be preferable to take into account the choice of academic group from the perspective of levels of disabilities.

TABLE IV: PERCENTAGE COMPLIANCE BETWEEN ADVANTAGED CDPS AND CHOICE OF ACADEMIC GROUP

\begin{tabular}{|c|c|c|c|c|c|c|}
\hline \multirow{2}{*}{\multicolumn{2}{|c|}{ Choice of Academic Group }} & \multicolumn{2}{|c|}{ Advantaged Career Development Patterns } & \multirow{2}{*}{$\begin{array}{c}\text { Total } \\
n\end{array}$} & \multirow{2}{*}{$\begin{array}{l}\text { Percentage } \\
\text { Compliance }\end{array}$} & \multirow{2}{*}{$\begin{array}{c}\text { Chi-square Test } \\
p \text { value (two-tailed) }\end{array}$} \\
\hline & & First group $n(\%)$ & Second and third groups $n(\%)$ & & & \\
\hline \multirow{3}{*}{$\begin{array}{c}\text { Overall } \\
\text { Advantaged }\end{array}$} & 1 & $81(73.6 \%)$ & $29(26.4 \%)$ & 110 & \multirow{3}{*}{$65.24 \%$} & \multirow{3}{*}{.015} \\
\hline & 2 & $17(56.7 \%)$ & $13(43.3 \%)$ & 30 & & \\
\hline & 3 & $11(45.8 \%)$ & $13(54.2 \%)$ & 24 & & \\
\hline \multirow{3}{*}{ Male } & 1 & $38(66.7 \%)$ & $19(33.3 \%)$ & 57 & \multirow{3}{*}{$63.2 \%$} & \multirow{3}{*}{.041} \\
\hline & 2 & $11(47.8 \%)$ & $12(52.2 \%)$ & 23 & & \\
\hline & 3 & $5(33.3 \%)$ & $10(66.7 \%)$ & 15 & & \\
\hline \multirow{3}{*}{ Female } & 1 & $43(81.1 \%)$ & $10(18.9 \%)$ & 53 & \multirow{3}{*}{$68.1 \%$} & \multirow{3}{*}{.557} \\
\hline & 2 & $6(85.7 \%)$ & $1(14.3 \%)$ & 7 & & \\
\hline & 3 & $6(66.7 \%)$ & $3(33.3 \%)$ & 9 & & \\
\hline \multirow{3}{*}{ Mild } & 1 & $40(75.5 \%)$ & $13(24.5 \%)$ & 53 & \multirow{3}{*}{$70.4 \%$} & \multirow{3}{*}{.005} \\
\hline & 2 & $7(43.8 \%)$ & $9(56.3 \%)$ & 16 & & \\
\hline & 3 & $4(33.3 \%)$ & $8(66.7 \%)$ & 12 & & \\
\hline \multirow{3}{*}{$\begin{array}{c}\text { Moderate to } \\
\text { severe }\end{array}$} & 1 & $14(93.3 \%)$ & $1(6.7 \%)$ & 15 & \multirow{3}{*}{$72.7 \%$} & \multirow{3}{*}{.061} \\
\hline & 2 & $3(100.0 \%)$ & $0(.0 \%)$ & 3 & & \\
\hline & 3 & $2(50.0 \%)$ & $2(50.0 \%)$ & 4 & & \\
\hline \multirow{3}{*}{$\begin{array}{c}\text { Severe/ } \\
\text { Extremely } \\
\text { Severe }\end{array}$} & 1 & $9(69.2 \%)$ & $4(30.8 \%)$ & 13 & \multirow{3}{*}{$63.6 \%$} & \multirow{3}{*}{.321} \\
\hline & 2 & $2(33.3 \%)$ & $4(66.7 \%)$ & 6 & & \\
\hline & 3 & $2(66.7 \%)$ & $1(33.3 \%)$ & 3 & & \\
\hline
\end{tabular}

\section{B. Comparison on the Difference in Career Development} Patterns between General Students and SEN Students at the Stage of Senior High School

Because the results of the scale were all converted into $\mathrm{T}$ score, this study used the test value of 50 to perform the single-sample t-test to compare and analyze the overall samples and subjects of different gender. According to the results of Table $\mathrm{V}$, the differences in means of realistic pattern, investigative pattern, artistic pattern, conventional pattern and mathematics and physics pattern between these two kinds of students all reached significance (.001). In addition, except for enterprise pattern, the mean of SEN students was lower than that of general students. The further comparison on male and female students from Table VI showed that, except for enterprise pattern and humanity pattern, there was a difference (.01) between male students with special education needs and general male students. In 
addition, the mean the male students with special education needs was lower than that of general male students. For female students with special education needs, there were differences between them and general female students in every career development pattern, except for enterprise pattern. In addition, the mean the female students with special education needs in social pattern was higher than that of general female students. Teacher counselors in high schools are advised to pay particular attention to this analysis results. The career development patterns of SEN students are different from those of general students. It is inadequate to directly apply the counseling measures for general students to the career counseling of SEN students.

\begin{tabular}{ccccc}
\multicolumn{2}{c}{ TABLE V: $T$-TEST ON CDPS OF GENERAL SOPHOMORES AND SEN STUDENTS IN SENIOR HIGH SCHOOL } \\
\hline Patterns & Mean & SD & $t$ value & $p$ value (two-tailed) \\
\hline Realistic & 35.48 & 19.475 & -13.445 & .000 \\
Investigative & 35.29 & 19.162 & -13.842 & .000 \\
Artistic & 42.29 & 19.121 & -7.271 & .000 \\
Social & 49.23 & 17.369 & -.795 & .427 \\
Enterprise & 50.50 & 12.485 & .725 & .469 \\
Conventional & 35.33 & 22.878 & -11.562 & .000 \\
Humanity & 49.94 & 14.251 & -.081 & .935 \\
Mathematics and & 41.15 & 15.106 & -10.561 & .000 \\
physics & & & & \\
\hline
\end{tabular}

TABLE VI: $T$-TEST ON CDPS OF GENERAL SOPHOMORES AND SEN STUDENTS OF DIFFERENT GENDER

\begin{tabular}{|c|c|c|c|c|c|c|c|c|}
\hline \multirow{2}{*}{ Patterns } & \multicolumn{2}{|c|}{ Mean } & \multicolumn{2}{|c|}{ SD } & \multicolumn{2}{|c|}{$t$ value } & \multicolumn{2}{|c|}{$p$ value (two-tailed) } \\
\hline & Male & Female & Male & Female & Male & Female & Male & Female \\
\hline Realistic & 39.56 & 29.43 & 19.418 & 17.991 & -7.487 & -13.090 & .000 & .000 \\
\hline Investigative & 38.13 & 31.08 & 19.614 & 17.719 & -8.428 & -12.224 & .000 & .000 \\
\hline Artistic & 40.05 & 45.60 & 19.335 & 18.376 & -7.167 & -2.739 & .000 & .007 \\
\hline Social & 46.26 & 53.64 & 17.365 & 16.475 & -3.002 & 2.530 & .003 & .013 \\
\hline Enterprise & 50.47 & 50.55 & 12.567 & 12.411 & .524 & .504 & .601 & .615 \\
\hline Conventional & 35.41 & 35.21 & 22.493 & 23.523 & -9.037 & -7.197 & .000 & .000 \\
\hline Humanity & 48.04 & 52.75 & 13.856 & 14.416 & -1.972 & 2.180 & .050 & .031 \\
\hline $\begin{array}{l}\text { Mathematics } \\
\text { and physics }\end{array}$ & 43.82 & 37.19 & 15.230 & 14.068 & -5.648 & -10.421 & .000 & .000 \\
\hline
\end{tabular}

\section{CONCLUSION AND SUGGESTIONS}

General Status and Compliance of Career Development Patterns of SEN students at the Stage of High School

1) The difference in gender has an effect on career development patterns: the score of male students in realistic pattern and investigative pattern is higher than that of female ones. The score of female students in artistic pattern and social pattern is higher than that of male ones. Female students with special education needs preferred humanity pattern, while male ones preferred mathematics and physics pattern. The result is consistent with general male and female students' choice of academic group.

2) The difference in levels of disabilities has an effect on career development patterns: the score of students with severe/extremely severe disability in conventional pattern is higher than that of those with other levels of disabilities.

3) The difference in choice of academic group has an effect on career development patterns: the score of the second group students in investigative pattern is higher than that of the first group ones. The score of the second group and the third group students in the mathematics and physics pattern is higher than that of the first group students.

4) There is a difference between the choice of academic group and advantaged career development patterns: the percentage compliance between them was $65.24 \%$, suggesting that $35 \%$ of the students failed to choose suitable group according to their occupational interest, work value, multiple intelligences and advantage of academic performance. The wrong choice rate of SEN students is higher than that of general students. Moreover, the compliance of female students with special education needs was higher than that of male ones. The compliance of students with mild disability and those with moderate to severe disability increased to $70.4 \%$ and $72.7 \%$, respectively.

In terms of the results of single-sample t-test on the career development patterns of general students and SEN students, the differences in the mean of realistic pattern, investigative pattern, artistic pattern, conventional pattern and mathematics and physics pattern all reached significance (.001). In addition, the mean of SEN students was lower than that of general students. There is no difference between the score of SEN students and general students of different gender. The score of female students with special education needs is in social pattern and humanity pattern is higher than that of general female students.

Based on the aforementioned findings, this study suggests that there should be full-time special education teachers providing SEN students with counseling of career planning which is different from that for general high school students. To enable SEN students to properly choose academic group, it is necessary to take into account their gender, levels of physical and psychological disabilities and advantaged career development patterns, and further interview typical representative subjects of advantaged career development patterns at various stages of career development to investigate the factors affecting career decision-making of SEN students, improve the self-awareness and accurate career decision-making of SEN students at stage and implement adaptive counseling for students with special 
education needs at high school stage under the concept of inclusion education.

\section{REFERENCES}

[1] American School Counselor Association. (2010). Ethical standards for school counselors. [Online]. Available: http://www.schoolcounselor.org/files/EthicalStandards2010.pdf

[2] American School Counselor Association, ASCA National Standards for Students, Alexandria, 2004.

[3] Ministry of Education. (2008). Selective Career Planning Course Guidelines for General High schools. Order Taichung (1) 0970011604B. [Online]. Available: http://hscr.cchs.kh.edu.tw/xoops2/uploads/career_planning.pdf

[4] Ministry of Education, 2012 Annual Statistical Report on Special Education, Taipei: Ministry of Education, 2012

[5] Ministry of Education, 2007 Annual Statistical Report on Special Education, Taipei: Ministry of Education, 2007.

[6] E. Szymanski, M. Enright, D. Hershenson, and J. Ettinger, "Career development theories, constructs and research: Implications for people with disabilities," in Work and Disability: Issues and Strategies in Career Development and Job Placement, E. M. Szymanski and R. M. Parker (Eds.), Austin, TX: Pro-Ed, 2003, pp. 87-132.

[7] H. C. Lin and H. Y. Huang, "A study on the performance of transition skills of special education needs students in (vocational) high school," Bulletin of Special Education, vol. 32, no. 2, pp. 17-46, 2007.

[8] D. W. Test, N. P. Aspel, and J. M. Everson, Transition Methods for Youth with Disabilities, Upper Saddle River, NJ: Prentice-Hall, 2006.

[9] P. Wehman, Life beyond the Classroom: Transition Strategies for Young People with Disabilities, 4th ed., Baltimore, MD: Paul H. Brookes, 2006.
[10] Y. H. Lin, "A study on the school life adaptation of special education needs students in normal class of vocational/ high schools Unpublished," Master's thesis, Department of Special Education, National Taiwan Normal University, 2005.

[11] C. Y. Li, "A study on the career maturity of special education needs students and general students in normal class in (vocational) high schools in Kaohsiung city," Master's thesis, Graduate Institute of Rehabilitation Counseling, National Kaohsiung Normal University, 2009.

[12] M. Smedley, E. M. Levinson, W. F. Barker, and D. L. DeAngelis, "Difference in career maturity among adjudicated and nonadjudicated male students with and without disabilities," Journal of Employment Counseling, vol. 40, pp. 108-122, 2003.

[13] E. D. Super, "A life-span, life-space approach to career development," Journal of Vocational Behavior, vol. 16, pp. 282-298, 1980.

[14] W. T. Wu, M. F. Chien, T. K. Hung, T. H. Shu, H. L. Tsou, C. H. Chang, and T. Y. Wu, "Construction of career development patterns of high school students and its meaning to continuing studying and career counseling," Journal of Research in Education Sciences, vol. 55, no. 2 29-72, 2010

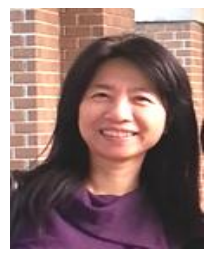

Chau Hsiao Lan is an assistant professor at National Taipei University of Education, Taiwan, ROC. She had been a special education teacher for 25 years, and earned her $\mathrm{PhD}$ of special education at National Taiwan Normal University in 2009. Her major field of interes are gifted education, individuals with disabilities education, and gifted students with disabilities. He research experience lies in the areas of special education needs students from primary to high school stages, especially twice exceptional students. Her doctor degree essay is "support service systems through strength and weakness analysis of gifted students with disabilities". 